\title{
Physical properties of the arctic summer aerosol particles in relation to sources at $\mathrm{Ny}$-Alesund, Svalbard
}

\author{
C G Deshrande* and A K KAMra \\ Indian Institute of Tropical Meteorology, Pune 411 008, India. \\ *Corresponding author. e-mail: cgdesh@tropmet.res.in
}

\begin{abstract}
Measurements of the number concentration and size distribution of aerosol particles in the size range of 0.5-20 $\mu \mathrm{m}$ diameter were made with an aerodynamic particle sizer at an Arctic site at Ny-Alesund, Svalbard in August-September 2007 during the International Polar Year 2007-2008. Data are analyzed to study the aerosol number concentration-wind speed relationships. The sea-salt particles of marine origin generated within the Arctic circle are identified as the main source of the Arctic summer aerosols. Total number concentration of aerosol particles increases with increase in wind speed, the increase being more when winds from open leads over the oceanic sector are reaching the station as compared to when winds from pack ice in other directions are reaching the station. The larger increase with winds from the oceanic sector is attributed to the enhanced bubble-breaking activity and increased entrainment of dimethyl sulphide particles at the sea surface. Although, the increase in total aerosol number concentration associated with the winds from the oceanic sector is spread over the whole range of particle sizes, the increase in coarse mode particles is more prominent than that in the accumulation mode particles. The age of airmass over pack ice is also an important factor to determine the aerosol concentration over the Arctic region. The process of rainout/washout of the aerosol particles due to drizzle/snowfall is an effective sink mechanism in the Arctic environment. The aerosol particle concentration starts decreasing within a few minutes from the start of these events but requires a few hours to restore to the normal background aerosol level after the end of event.
\end{abstract}

\section{Introduction}

The Arctic is particularly vulnerable to the effects of global warming and has been found to be shrinking fast in the last few decades. In recent years, the Arctic temperature increases are reported to be double as compared to those found at more southerly latitudes (Hassol 2005; IPCC 2007). Perhaps the most spectacular results of Arctic shrinkage are the sea ice loss and Arctic methane release (Comiso 2002; Serreze et al. 2007). The prevailing global air currents make the Arctic area the fallout region for long-range transport of air pollutants from low latitudes. As a consequence, the pollutant concentration at some places exceeds the levels at densely polluted urban areas. These changes, though remote from the population centers, can significantly affect the whole planet through their impacts on global climate. Monitoring and study of environmental factors in Arctic are therefore likely to provide signals for early detection of future climate changes. Such efforts are needed to develop policies for planning and management strategies for mitigation of environment

Keywords. Arctic aerosol; sources of aerosols; size distribution; Ny-Alesund. 
challenges. Worldwide implications of social, economic and climate change aspects of such environmental changes have led to the organization of large numbers of international efforts and programmes to study the Arctic environment in recent years. Declaration of 2007-2008 as the International Polar Year (IPY) by the United Nations was one such step in this direction. The present paper describes some aerosol measurements made at $\mathrm{Ny}-$ Alesund, Svalbard during the first Indian Arctic Expedition during IPY.

Atmospheric aerosols are known to affect the radiation budget of the atmosphere, both directly and indirectly. However, scarcity of data on the physical and chemical characteristics of aerosols in some regions has been one of the factors for the uncertainty in assessment of the effect of aerosols in global climate models (e.g., Kasibhatla et al. 1997; Heintzenberg et al. 2000). Recent studies on climate modeling reveal the importance of the Arctic region in view of global climate change, as these models predict the largest increase in the annual mean temperature over the Arctic (Hassol 2005). Therefore, various characteristics of the Arctic aerosol have been widely studied over the Arctic ocean (Lannerfors et al. 1983; Covert et al. 1996), during Arctic haze (Heintzenberg 1981, 1987; Barrie and Barrie 1990; Leck et al. 2001; Ricard et al. 2002) and fog conditions (Leck and Bigg 1999; Heintzenberg et al. 2006). Leck et al. (2002) studied chemical composition, sources and method of production of cloud condensation nuclei (CCN) over the pack ice covered Arctic ocean in summer. The ocean surface microlayer, its properties and effects on gas transfer and the implications vis-a-vis climate change have been reviewed in a series of articles (Liss and Duce 1997). Bigg et al. (2004) and Matrai et al. (2008) have reported that the Arctic surface micro-layer acts as a source of organic precursor aerosol.

Recently, more systematic and continuous efforts were initiated to measure the particle size distribution and chemical composition at Zeppelin station, Ny-Alesund, Svalbard, which is located on a hill-top $474 \mathrm{~m}$ above mean sea level. Measurements at this station show a very strong seasonal dependence on aerosol characteristics (Strom et al. 2003; Engvall et al. 2008) and the airmass transport and potential sources of new particle formations are reported as important factors modulating the physical and chemical properties in the Arctic. Long term aerosol and black carbon measurements over Arctic are analysed to understand the seasonal cycle of high concentration of Arctic winter/spring aerosol and its transition to low concentration of Arctic summer aerosol (Sharma et al. 2004; Eleftheriadis et al. 2009; Garrett et al. 2011; Browse et al. 2012). Recent observations of Hong
Geng et al. (2010) made just one week before our measurements were made in the same campus, reported that the dominance of reacted seasalt particles of marine origin is followed by those of carbonaceous and mineral dust particles. The bubbles bursting at the ocean surface which is primarily a consequence of wave-breaking activity and starts as soon as the wind speed exceeds $3-4 \mathrm{~ms}^{-1}$ produce both film and jet drops and are a potential source of sea-salt particles in the oceanic atmosphere (Blanchard and Woodcock 1957; Blanchard 1963). In the Arctic region, Leck et al. (2002) has examined the dependence of the aerosol number concentration on wind speed.

In addition to the particle generation sources, discussed above, several atmospheric processes act as sinks for the particles in the atmosphere. Among them, the rainout and washout processes occurring during rainfall/snowfall events are considered as the main atmospheric processes for removal of atmospheric particles in the Arctic. Efficiency of these mechanisms is strongly determined by the rainfall rate and the size of aerosol particles and hydrometeors (e.g., Pruppacher and Klett 2000 and the references therein). Garrett et al. (2011) and Browse et al. (2012) have demonstrated the importance of this mechanism in the Arctic summer.

The first Indian Arctic Expedition during the IPY 2007-2008 programme provided an opportunity to conduct aerosol number size distribution measurements at Ny-Alesund, Svalbard $\left(78.9^{\circ} \mathrm{N}, 11.9^{\circ} \mathrm{E}\right)$. Here, the measurements made from August 8 to September 2, 2007 and their analyses with respect to the wind speed, wind direction and age of airmass over pack ice are described in order to identify the source of the Arctic summer aerosols. Observations made on the wet removal of aerosols by the scavenging process during the rain/snowfall events are also examined.

\section{The experimental site and set-up}

Recognizing the importance of the generation and transportation processes of the coarse mode particles in the Arctic environment in summer, it was decided to use an Aerodynamic Particle Sizer (APS, Model 3321 of TSI Inc.) to measure the number concentration and size distribution of aerosol particles in the size range of $0.5-20 \mu \mathrm{m}$ diameter spread over 52 channels during August 8September 2, 2007 at the Norwegian Polar Institute (NPI) station in an instrument-park at NyAlesund. Figure 1 shows the map of Svalbard, an archipelago in the Arctic Ocean. Ny-Alesund is located at the remote northern settlement of 


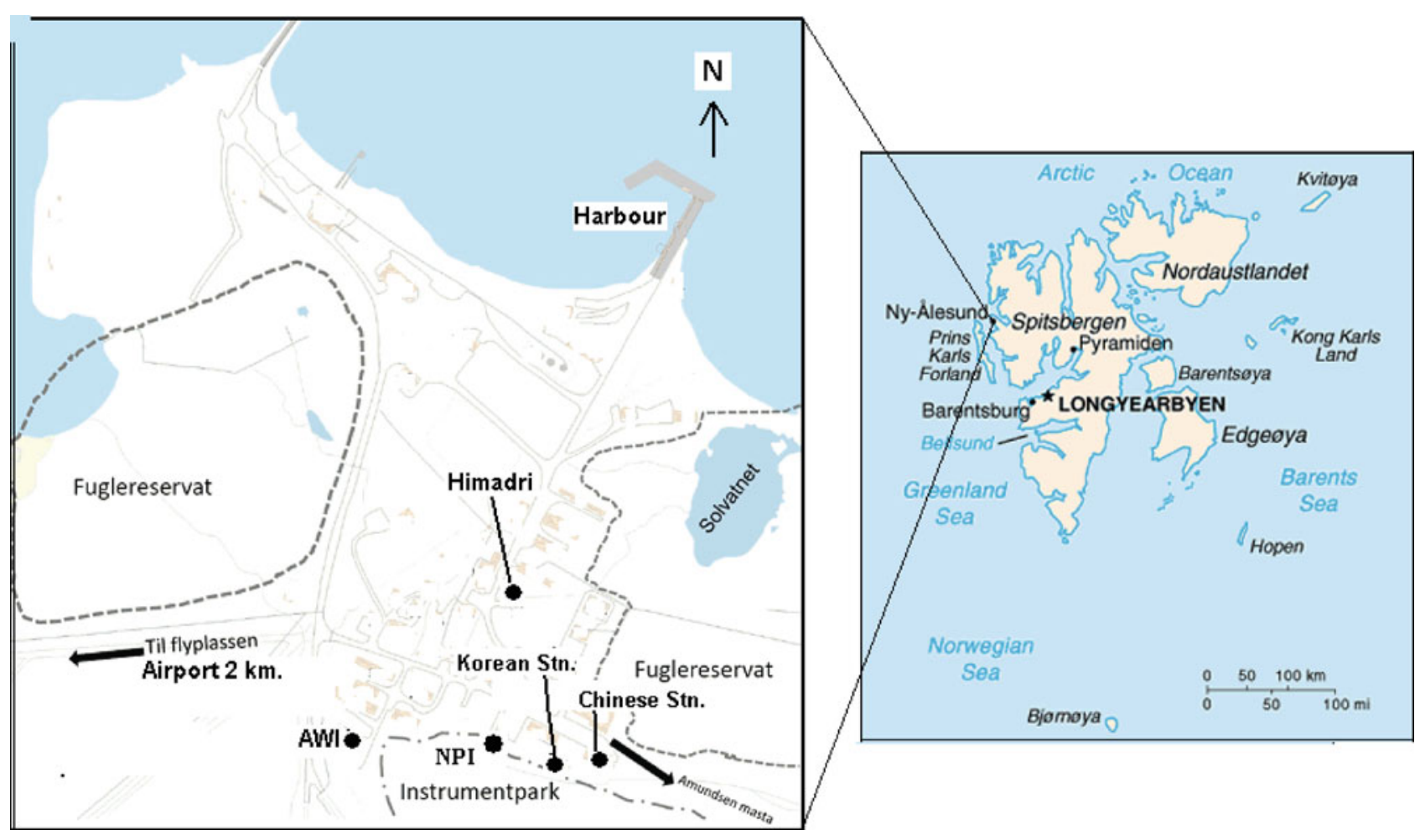

Figure 1. Map of Svalbard in the Arctic region showing the location of Ny-Alesund. Inset shows some important locations and the Indian station 'Himadri', alongwith some other research stations.

Spitsbergen and is about $1231 \mathrm{~km}$ from the north pole. The Ny-Alesund township encompasses only research stations of various nations including Indian station 'Himadri' engaged in environmental and earth science research (figure 1). Its population comprises of only 70 scientists and 30 logistic personnel during the summer period. Limited aircraft and vehicles are utilized to protect the eco-system of the Arctic.

Continuous measurements of the particle size distribution were conducted at every 5-minute intervals using the APS system with its inlet fixed at $7 \mathrm{~m}$ above the ground and projected to face the prominent wind direction. The sampling site is located at the extreme southeast end of the town such that minimum human activity and vehicular traffic contaminate the sampling air. The $\mathrm{Ny}$ Alesund harbor with limited ship traffic is located about $500 \mathrm{~m}$ away from the measuring site and hence the chances of contamination due to ship's smoke are minimum. Although the local airport is about $2 \mathrm{~km}$ away from measuring site and has very limited air traffic, the data during the aircraft landing and take-off periods is not considered in this analysis. The meteorological measurements were made using an automatic weather station with the sensors fixed at $10 \mathrm{~m}$ above ground level at the Alfred Wegener Institute (AWI) station located $100 \mathrm{~m}$ away from our sampling site.

\section{Back trajectories and weather}

The 5-day backward trajectories arriving at a height of $10 \mathrm{~m}$ at $\mathrm{Ny}$-Alesund at $1200 \mathrm{UT}$ on 4 fairweather days and all other days drawn from the HYSPLIT transport and dispersion model (NOAA, Air Research Laboratory) are plotted in figure 2 . On 4 fair-weather days the backward trajectories originate near north pole and always remain within $80^{\circ}$ circle. However, on other days, the air masses generally travel long distances and atleast on 5 days, backward trajectories extend up to the Arctic Circle at $63.5^{\circ} \mathrm{N}$ latitude which is the typical climatic airflow in this region. The airmass backtrajectory analysis at the height of 100, 500, $1000 \mathrm{~m}$ carried out by Hong Geng et al. (2010) at NyAlesund during the same period also show that the summer time airmasses sampled in these measurements originated from the Arctic ocean and stayed over it for long time. Further, observations show that the transport of anthropogenic airmass during summer period is not as efficient as that during the winter period (Eneroth et al. 2003; Strom et al. 2003). Pole-ward shift of the polar front in summer weakens the transport of pollutants from the mid-latitude to Arctic.

The meteorological measurements made at the AWI station along with our measurements of total number concentration of the aerosols $(0.5-20 \mu \mathrm{m})$ 

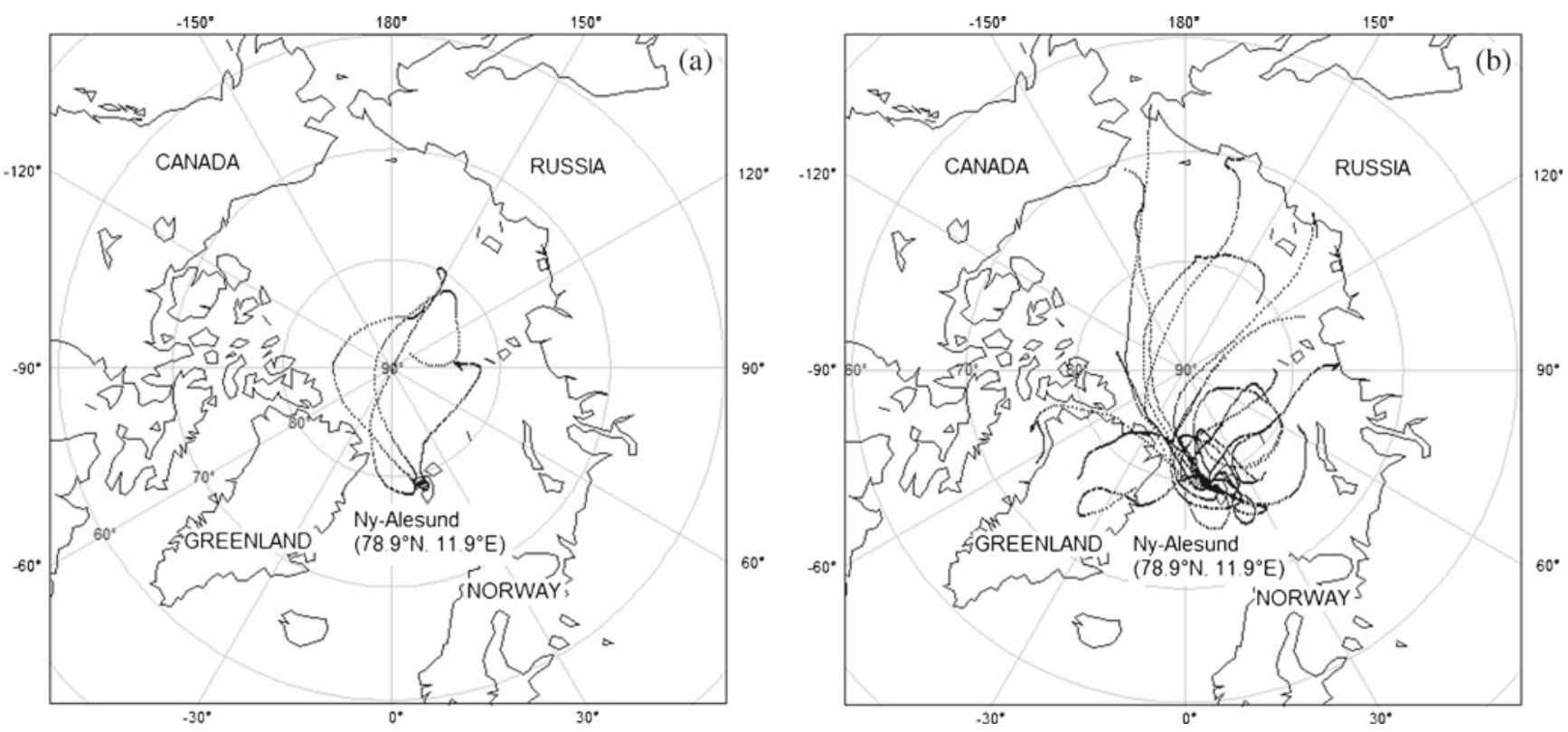

Figure 2. The 5-day backward trajectories reaching Ny-Alesund at $10 \mathrm{~m}$ level at $1200 \mathrm{UT}$ on (a) fair-weather days and (b) all other days.

during the observation period are shown in figure 3. The Arctic winds are characterized by high directional consistency but show large variations of $0.5-10 \mathrm{~ms}^{-1}$ in wind speed. The dominant wind direction during this period is northwesterly with occasional changeover to southeasterly. The air temperature varied from -1.6 to $6.8^{\circ} \mathrm{C}$, the relative humidity is mostly above $80 \%$ and the atmospheric pressure varied from $994 \mathrm{hPa}$ to $1018 \mathrm{hPa}$. The steady decreasing trend in temperature and relative humidity observed during our measurement period is due to the end of the Arctic summer period on September 30.

\section{Total particle number concentrations}

The 5-minute average values of total particle number concentration are plotted in figure 3 . The total number concentration ranged from 0.11 to 6.06 particles $\mathrm{cm}^{-3}$ with an average value of 0.84 particles $\mathrm{cm}^{-3}$ during observation period from August 8 to September 2, 2007. Heintzenberg et al. (2006) reported that number concentration of accumulation particles of size $0.25-1 \mu \mathrm{m}$ during Arctic summer ranged from 0.72 to 1.4 particles $\mathrm{cm}^{-3}$ with an average number concentration of 1.1 particles $\mathrm{cm}^{-3}$ of geometric mean diameter of $0.427 \mu \mathrm{m}$. These values are approximately of the same order as those of the background aerosol concentration in the Arctic summer. The wet scavenging processes at high relative humidities and warm temperatures are
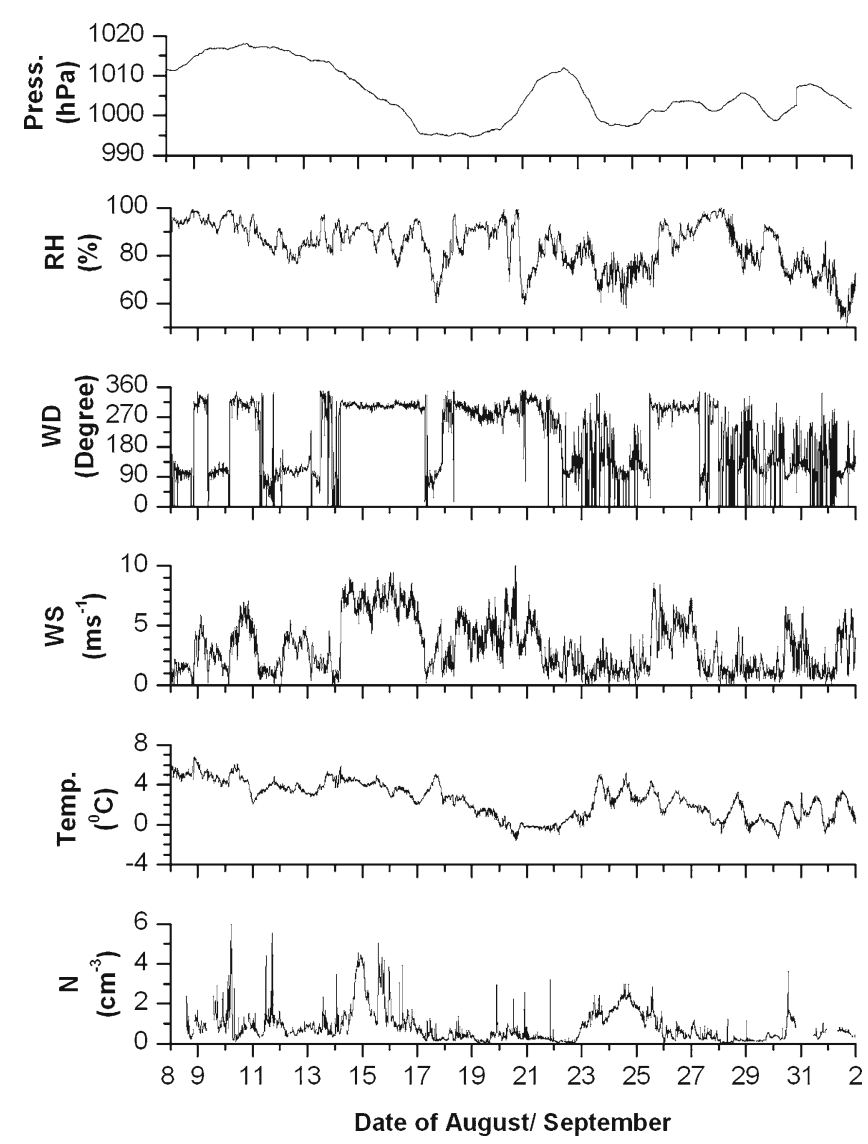

Figure 3. Variations of various meteorological parameters along with total number concentration of particles in the size range of $0.5-20 \mu \mathrm{m}$ diameter measured at Ny-Alesund from August 8 to September 2, 2007. 


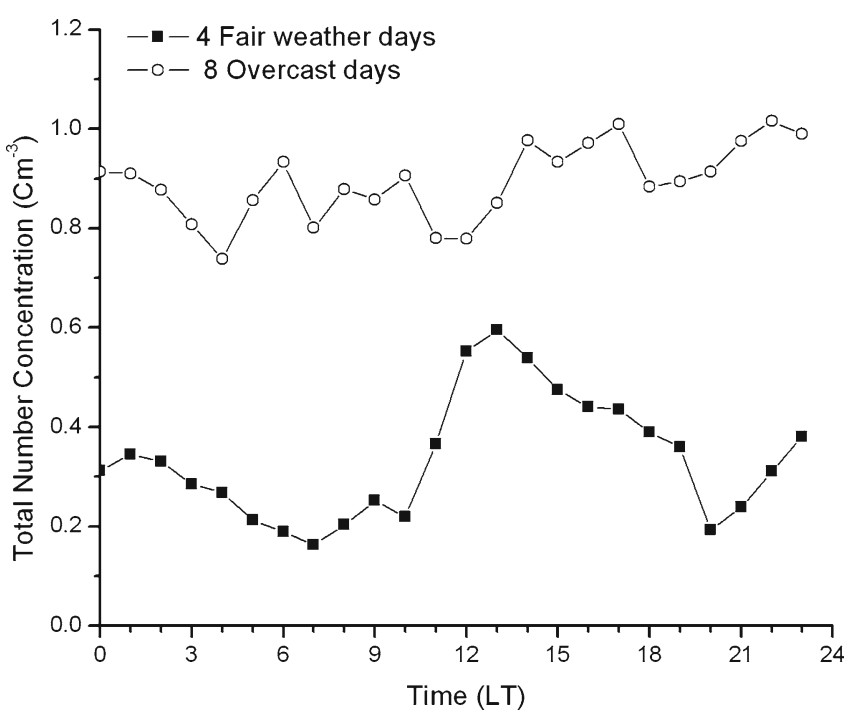

Figure 4. The diurnal variations of hourly-averaged total particle concentration for 4 fair-weather and 8 cloudy (overcast) days at $\mathrm{Ny}$-Alesund.

considered mainly responsible for keeping aerosol concentrations at background level during Arctic summer. The reduction of atmospheric pressure to about $994 \mathrm{hPa}$ and the associated changes in relative humidity during August 17-21 were caused with the passage of a system which produced rain and snow on August 19 and 20 at Ny-Alesund. The atmospheric temperatures also reduced from August 17 to 23. The changes in particle concentration associated with these events are analysed and discussed in detail in section 7 .

Figure 4 shows the average diurnal variation of the hourly-averaged total number concentration on 4 fair-weather days (August 17, 22, 28, $30,2007)$ at $\mathrm{Ny}$-Alesund. The fair-weather days are categorized as when there are less than 2 octa clouds, no rain/snowfall, and winds are less than $4 \mathrm{~ms}^{-1}$. Total particle concentration increases from 0800 LT, remains high up to 1800 LT and then it starts decreasing. As the sun is available all the time in the Arctic summer, the diurnal variation in the particle number concentration may be due to the larger activity of photo chemistry at noon-time when the solar radiation is maximum. Supporting such an explanation is the fact that no such diurnal variation in aerosol concentration, also plotted in figure 4 , is observed on 8 cloudy days with overcast skies (August 8, 9, 12, 15, 19, 20, 25, 27; 2007). The higher number concentrations observed on cloudy days as compared to those on fair-weather days can be associated with the marine aerosols produced due to higher winds approaching from the pole. The variability of particle number concentration with wind speed is discussed in detail in section 6 .

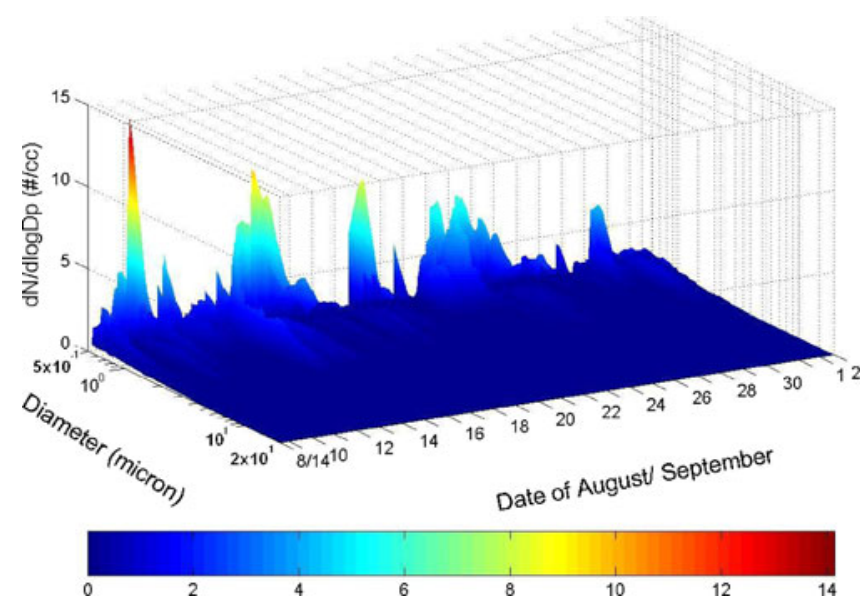

Figure 5. Three dimensional particle number size distribution measured at $\mathrm{Ny}$-Alesund from August 8 to September 2,2007 .

\section{Particle number size distributions}

A total of 7320 aerosol particle size distributions, each averaged over a period of 5-minutes, were measured during the period of our observations. Figure 5 shows the time-series of 3-dimensional size distributions over the period of measurement. In general, size distributions are monomodal with a peak at $0.96 \mu \mathrm{m}$ diameter and show no typical diurnal variation. Earlier observations of Heintzenberg (1980) at Ny-Alesund show similar particle number concentrations and the size distribution trends which are typical of the global background aerosols. The concentration of accumulation mode particles $(\mathrm{Dp}<1 \mu \mathrm{m})$ is higher as compared to those of coarse mode particles ( $\mathrm{Dp}>1 \mu \mathrm{m})$ in our measurements. This is consistent with earlier observations of the abundance of Aitken/accumulation mode particles in Arctic summer (Ferek et al. 1995; Heintzenberg et al. 2006; Engvall et al. 2008). While the number concentration of accumulation mode particles show large variations with time, the concentration of coarse mode particles remains almost constant. Variabilities of these two modes of particles are further analysed and discussed in the following sections.

\section{Variability of the particle number concentration with wind speed and wind direction}

The dominant wind direction at Ny-Alesund during August is northwesterly/northerly, occasionally changing to southeasterly. The polar diagram in figure 6 shows that the total particle number concentration increases when winds are northwesterly 


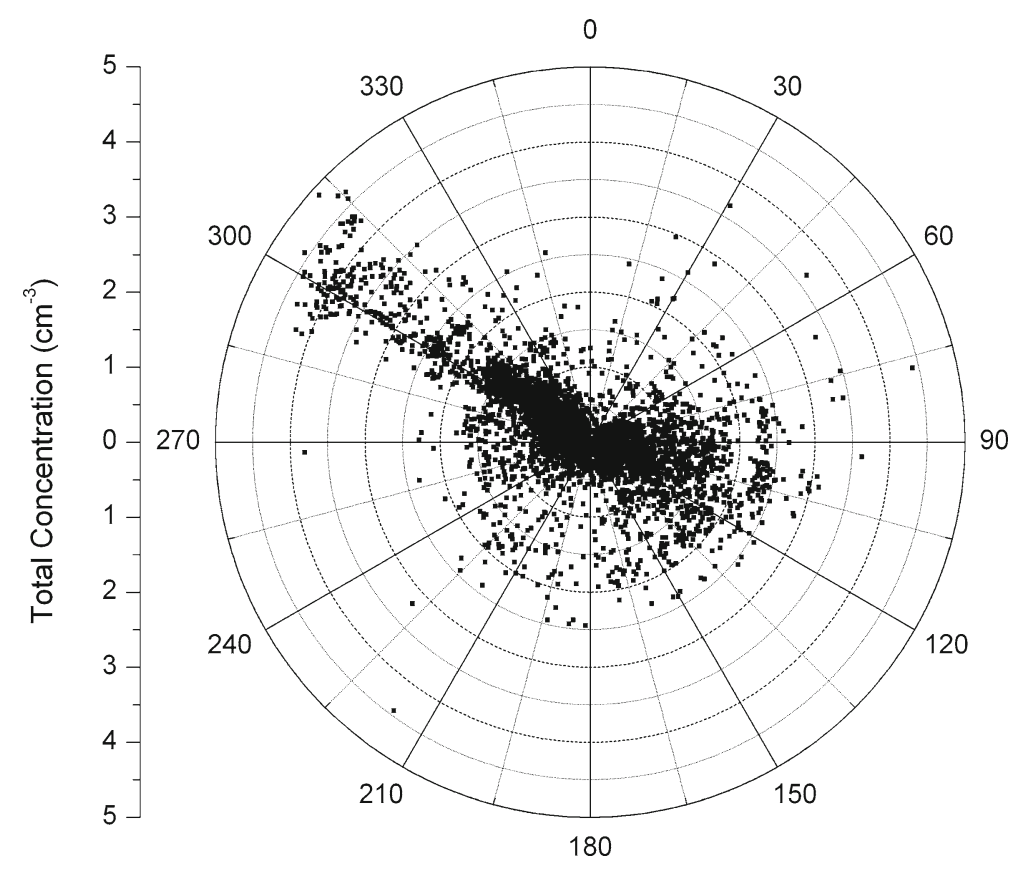

Figure 6. Wind-rose diagram showing the variation of the total particle number concentration with respect to wind direction at Ny-Alesund.

as compared to those when these are southeasterly. Total number concentrations are observed to be less than 2.5 particles $\mathrm{cm}^{-3}$ in $99 \%$ of cases when winds are from the $330^{\circ}-270^{\circ}$ sector but increase upto 5 particles $\mathrm{cm}^{-3}$ when the winds are from $270^{\circ}$ to $330^{\circ}$ sector.

The total particle number concentration data is separated when the winds are from different sectors. The 5-minute averaged values of total particle concentration are averaged for every $1 \mathrm{~ms}^{-1}$ wind speed range at $\mathrm{Ny}$-Alesund and are plotted in figure 7. The error bars and labels in this figure show the standard deviations of average values and the number of samples averaged for a particular wind-speed range, respectively. The total particle number concentration remains constant at about 0.5 particle $\mathrm{cm}^{-3}$ upto a wind speed of $4-5 \mathrm{~ms}^{-1}$ and then sharply increases as wind speed increases from 5 to $9 \mathrm{~ms}^{-1}$. The number of samples collected at a given wind speed are labeled and shown in figure 7 . These large numbers of samples collected at given wind speed support the reliability of such increases in total particle concentration with wind speed.

To study the dependence of particle concentration on wind direction, we have divided our data into three different categories depending upon whether the winds are (i) from all directions, (ii) from $270^{\circ}$ to $330^{\circ}$ which we shall call as oceanic sector, or (iii) from $330^{\circ}$ to $270^{\circ}$. The total number concentration vs. wind speed scatter diagrams for these three categories are plotted in figure 8. The

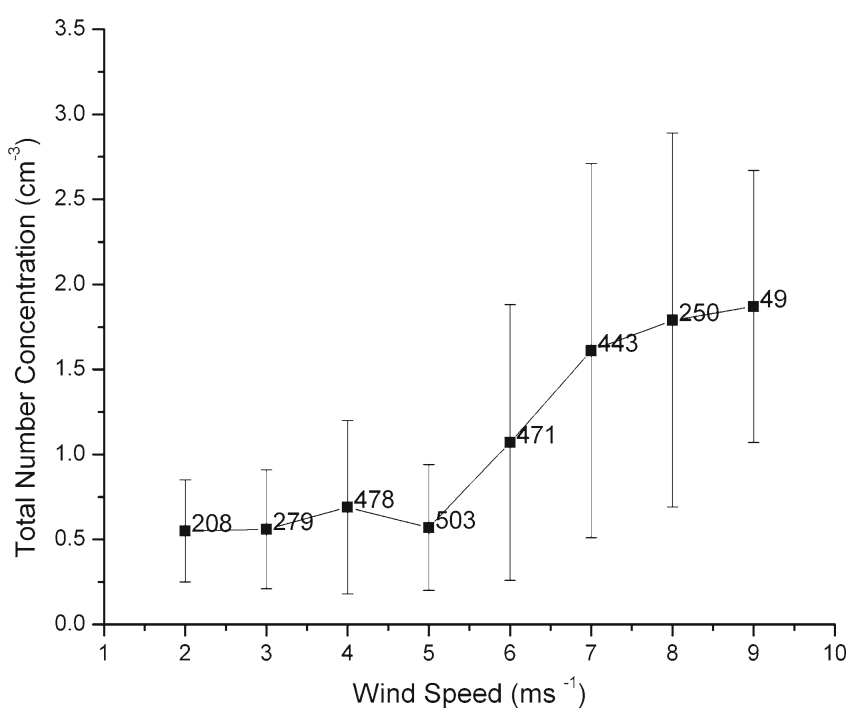

Figure 7. Average total particle concentrations for every $1 \mathrm{~ms}^{-1}$ wind speed interval at $\mathrm{Ny}$-Alesund. The error-bars and labels show the standard deviation of average values and the number of samples averaged for a particular wind speed, respectively.

regression line relating the total particle concentration $\mathrm{N}$ and average wind speed $\mathrm{U}$ is expressed as

$$
\log _{10} \mathrm{~N}=\mathrm{kU}+\mathrm{m} \text {, }
$$

where $\mathrm{k}$ and $\mathrm{m}$ are constants. Table 1 shows the values of $\mathrm{k}, \mathrm{m}$ and correlation coefficient $(\mathrm{R})$ calculated from regression line for the three different 

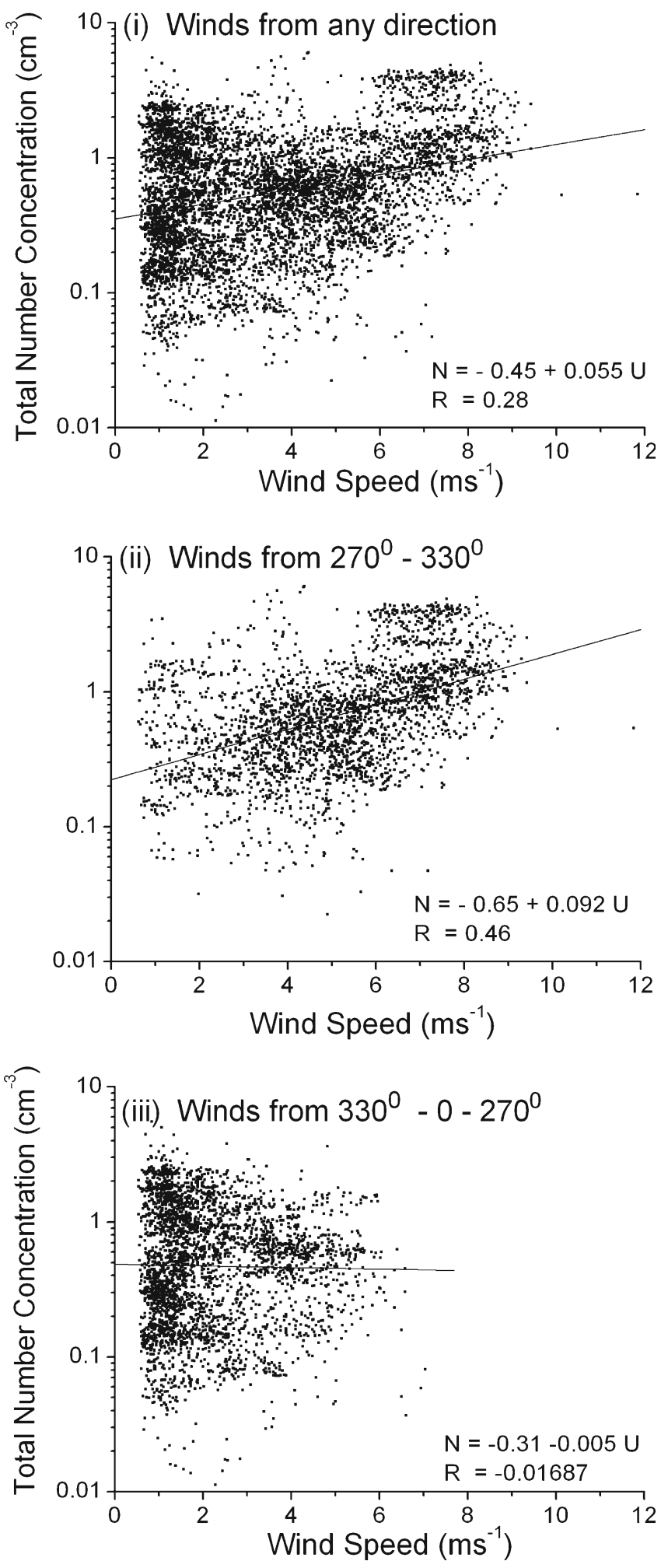

Figure 8. Total particle number concentration and wind speed scatter diagram considering when winds are (i) from all directions, (ii) from $270^{\circ}$ to $330^{\circ}$, and (iii) from $330^{\circ}-$ $270^{\circ}$.

categories of wind direction and for accumulation/ coarse mode particles. Table 1 and figure 8 show that there is no significant correlation between particle concentration and wind speed when winds are considered from all directions or from the $330^{\circ}-0-270^{\circ}$ sector. The correlation between particle concentration and wind speed becomes even slightly negative when winds are from the $\left(330^{\circ}-\right.$ $270^{\circ}$ ) sector, suggesting that the particle concentration, in this case, no longer increases with increasing wind speed. However, when winds flowing from the oceanic sector $\left(270^{\circ}-330^{\circ}\right)$, the correlation coefficient between the particle concentration and wind speed increases to the relatively much higher value of 0.46 , which is significant at $39 \%$ level. Moreover, the value of correlation coefficient further increases to 0.59 in the case where particles $>1 \mu \mathrm{m}$ are considered. This indicates that when the winds arrive from the $270^{\circ}-330^{\circ}$ sector, there is a tendency of the particle concentration to increase with the wind speed, which is not seen, when the wind is from the other sectors. So wind is one of the contributing factors for the enhancement, though not totally. Table 1 also shows values of $\mathrm{k}, \mathrm{m}$ and $\mathrm{R}$ reported by Leck et al. (2002) for Arctic measurements, Smith et al. (1989) and O'Dowd and Smith (1993) over North Atlantic ocean. The values of $\mathrm{R}$ over Arctic region are comparable but those over North Atlantic ocean are slightly higher than in our case when winds are from the oceanic sector. Considering the location of $\mathrm{Ny}$-Alesund, the polar winds approaching from the oceanic sector have a long journey over the open ocean during the Arctic summer causing the wavebreaking activity at high wind speed. On the other hand, when winds are from $\left(330^{\circ}-270^{\circ}\right)$ sector, they have to travel the last 1-2 days over Svalbard. The passage of airmass over bare mountain/land may contribute to mineral dust particles in this case (Teinila et al. 2003; Hong Geng et al. 2010). However, in the Arctic summer, about $60 \%$ of the land is covered with ice and glaciers. The passage of airmass over the ice surfaces is not likely to contribute much to the mineral dust particles. Our observations confirm that particle concentration does not depend on wind speed when winds are from the $\left(330^{\circ}-270^{\circ}\right)$ sector.

While investigating the relationship between total aerosol concentration and wind speed, the role of local aerosol production over a large icecovered region is considered to be an important factor as compared to that over the open ocean. Leck and Persson (1996) reported an order of magnitude decrease in aerosol volume concentration after $48 \mathrm{hr}$ of transport from the ice edge. The residence time of sampled air over pack ice for more than 4 days is considered as selection criterion by Leck et al. (2002) to study the particle concentrationwind speed relation. Decrease of particle concentration after a travel time of $24 \mathrm{hr}$ from ice edge is reported by Heintzenberg et al. (2006) over the Arctic ocean during different expeditions. 
Table 1. Statistics of the dependence of particle concentration on wind direction and wind speed.

\begin{tabular}{|c|c|c|c|c|c|c|}
\hline Wind direction & $\begin{array}{l}\text { Particle size } \\
\quad(\mu \mathrm{m})\end{array}$ & $\begin{array}{l}\text { Wind speed } \\
\qquad\left(\mathrm{ms}^{-1}\right)\end{array}$ & $\mathrm{k}$ & $\mathrm{m}$ & $\mathrm{R}$ & $\begin{array}{c}\text { Number of } \\
\text { samples }\end{array}$ \\
\hline Category (i) Winds from all directions & $0.5-20$ & $2-12$ & 0.055 & -0.45 & 0.28 & 7320 \\
\hline Category (ii) Winds from $\left(270^{\circ}-330^{\circ}\right)$ & $0.5-20$ & $2-12$ & 0.092 & 0.065 & 0.46 & 2912 \\
\hline Category (iii) Winds from $\left(330^{\circ}-270^{\circ}\right)$ & $0.5-20$ & $2-8$ & -0.005 & -0.31 & -0.01 & 4408 \\
\hline Category (ii) Winds from $\left(270^{\circ}-330^{\circ}\right)$ & $0.5-1$ & $2-12$ & 0.090 & -0.82 & 0.41 & 2912 \\
\hline Category (ii) Winds from $\left(270^{\circ}-330^{\circ}\right)$ & $1-20$ & $2-12$ & 0.175 & -1.28 & 0.59 & 2912 \\
\hline Leck et al. (2002) & $0.5-1.71$ & $5-12$ & 0.094 & -0.67 & 0.65 & Not known \\
\hline \multicolumn{7}{|l|}{ Arctic region } \\
\hline Smith et al. (1989) & $0.8-3.0$ & Upto 34 & 0.089 & -0.62 & 0.80 & Not known \\
\hline \multicolumn{7}{|l|}{ North Atlantic } \\
\hline O'Dowd and Smith (1993) & $0.5-16$ & $4-8$ & 0.05 & -1.1 & 0.75 & Not known \\
\hline North Atlantic & & & & & & \\
\hline
\end{tabular}
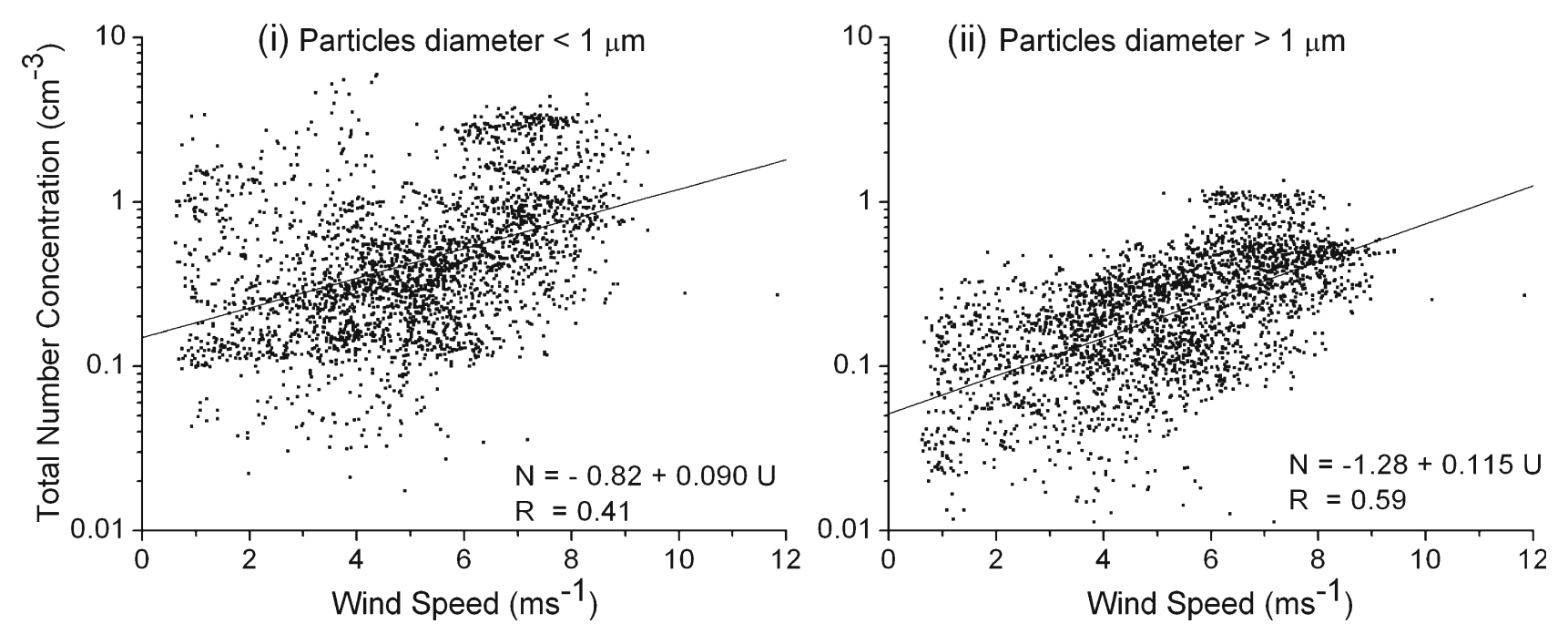

Figure 9. The total particle number concentration and wind speed scatter diagrams when the winds are from $270^{\circ}-330^{\circ}$ in case of (i) the accumulation mode particles $(\mathrm{Dp}<1 \mu \mathrm{m})$ and (ii) the coarse mode particles $(\mathrm{Dp}>1 \mu \mathrm{m})$.

Figure 9 shows the scatter diagrams of particle concentration with wind speed separately for the accumulation mode and the coarse mode particles when the winds are from the oceanic sector. The $\mathrm{k}, \mathrm{m}$ and $\mathrm{R}$ values for these two modes are given in table 1 . The correlation between total number concentration and wind speed is higher for coarse mode than for the accumulation mode particles. These results support the result of Leck et al. (2002) that film drop generation is less dependent and the jet drop production are more dependent on wind speed in Arctic pack ice area than over the open ocean. The dominance of jet drop mode over the Arctic ocean under the prevailing high winds reported by Nilsson et al. (2001) also supports our observation.

\section{Changes in particle size distribution during rainfall/snowfall events}

Events of drizzle or snowfall occurred on several occasions during our observation period at this station. Figure 10 shows the 3-dimensional time-series of particle size distribution during the events of rain/drizzle and snowfall on August 19 and 20, 2007, respectively. The northwesterly winds with speed of about $5 \mathrm{~ms}^{-1}$ prevailed during these events. Unfortunately, the exact amount of rain/ snowfall was not available so we could not compare the relative scavenging efficiencies of rain and snow. During the spell of drizzle from 0000 UT to 1100 UT on August 19, snowfall was also noticed on the hills surrounding $\mathrm{Ny}$-Alesund. 


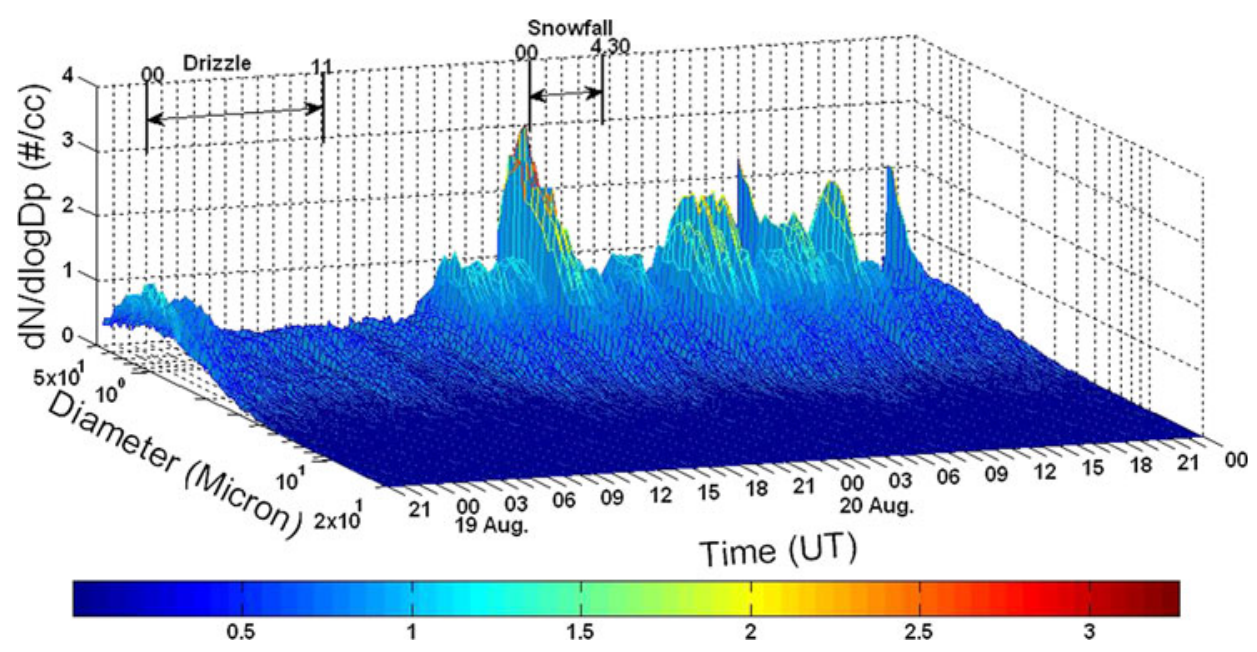

Figure 10. Three-dimensional particle number size distributions measured during events of rain on August 19,2007 and snowfall on August 20, 2007 at Ny-Alesund.

A dramatic reduction in concentration of particles of $<1 \mu \mathrm{m}$ diameter was observed with the start of drizzle activity at the station. Particle concentration continued to be low till 1300 UT whereas the drizzle had stopped at about 1100 UT. The aerosol size distribution retained its normal values at about 1600 UT. In this event, the atmosphere took about $4-5$ hours to retain its normal level of the background particle size distribution.

In the event of snowfall, the Ny-Alesund station experienced frequent spells of snowfall from 0000-0430 UT and again a few spells of snowfall from 1000-1400 UT on August 20, 2007. The aerosol particle size distribution shows a decrease in particle concentration associated with snowfall activity at the station (figure 10). The concentration of particles of $<1 \mu \mathrm{m}$ diameter decreased after 0000 UT and remained low upto 0700 UT with marginal increase at about 0004 UT. As the snowfall at the station stopped at about 0430 UT, the aerosol size distribution also started to retain its normal background level and attained it at about 0800 UT. The particle size distribution also showed a decrease in particle concentration corresponding to a few events of snowfall that occurred between 1000-1400 UT. During these periods also, the aerosol particle concentration retained its normal background level only at 1700 UT.

Figure 10 clearly shows that both, rain and snow, effectively remove the aerosol particles of all sizes from the atmosphere. Rainfall, in particular, seems to rapidly and greatly reduce the concentration of smaller particles, even in the range of Greenfield Gap. The fact that coarse mode $(>2 \mu \mathrm{m})$ particle concentration is very low during rainfall period, indicates that impaction mechanism of scavenging is very effective in this case.

\section{Discussion}

Several past long-term measurements at Zeppelin station in $\mathrm{Ny}$-Alesund are made at a higher elevation $(474 \mathrm{~m})$. The present studies are carried out at low elevation which are important in view of lower boundary layer height, weak convective mechanisms, increasing local activities and low ice cover over oceans during summer seasons in the Arctic environment. This is particularly important in view of the marked differences observed in optical aerosol parameters by Tomasi et al. (2007) at coastal and high altitude sites in Antarctica. Continuous measurements or at least periodic checks of this type are essential to keep a watch considering the growing importance of different aspects of the global warming and its largest impact in the Arctic area (Hassol 2005).

Arctic climatology, generally, dictates that the long-range transport of anthropogenic aerosols from southern latitudes is weaker in summer than in winter. Long term aerosol and black carbon measurements made at Zeppelin station and over north American Arctic and Canadian Arctic show high concentration of anthropogenic particles in the Arctic haze which can be attributed to longrange transport from the northern/central Russia and Europe during Arctic winter/spring (Sharma et al. 2004; Eleftheriadis et al. 2009). The backward trajectory analysis also suggests that the transport from anthropogenic sources is not effective due to the absence of sufficient pressure gradient in the summer (Engvall et al. 2008).

The summer Arctic aerosols are characterized with high Aitken mode and very low accumulation mode particle concentrations (Ferek et al. 1995; Heintzenberg et al. 2006; Engvall et al. 2008). Present observations at $\mathrm{Ny}$-Alesund confirm this. 
The airmasses arriving at the Arctic region during the summer period are from cleaner regions following oceanic routes and thus their transport is much slower (Stohl 2006). The source of summer Arctic particles is mainly identified as of marine origin. Concentration of reacted sea-salt particles is followed by carbonaceous and mineral dust particles, with minor contribution of sulfate, water soluble organic matter and black carbon (Hong Geng et al. 2010; Tomasi et al. 2012). During the summer period aerosols at $\mathrm{Ny}$-Alesund are also impacted by Asian dust events, smoke generated by boreal forest fires in Siberia or biomass burning in the Eurasian region (Tomasi et al. 2007). The longterm trend of the summer aerosol optical depth at $500 \mathrm{~nm}$ was estimated to be between $1.6 \%$ and $2 \%$ per year over 30 years (Tomasi et al. 2007).

The enhanced photo chemical activities due to all-day-long daytime in the Arctic summer results in the production of nitric acid that reacts with seasalt particles. Also, the rapid increase of shipping traffic due to the sea ice melt in summer in these regions contributes to an increase in the level of $\mathrm{NO}_{\mathrm{x}}$ and some precursor secondary aerosols (Hong Geng et al. 2010). The solar radiation to oxidize the biogenic precursor gases released due to ice melting increase during summer. The Arctic ocean is a strong source of dimethyl sulphide (DMS) in summer time. The DMS concentration during the Arctic summer increases significantly as compared to the background concentration (Ferek et al. 1995). The increase in ice melting in summer in the open leads to increase in the biological activity of the region resulting in enrichment of DMS and its biogenic precursor DMPS, dissolved combined-amino acid (DCAA), proteins and chlorophyll-a in microlayer, which work as potential sources of the Arctic summer aerosols (Bigg et al. 2004; Matrai et al. 2008).

Our observation of the average aerosol number concentration of 0.84 particles $\mathrm{cm}^{-3}$ represents the background concentration in the Arctic region. The concentration of accumulation mode particles is found to be higher than that of coarse mode particles in the Arctic summer. The fresh and reacted sea-salt as well as carbonaceous and mineral dust particles are the main components of particles in the Arctic summer. The mineral dust particles from bare land may contribute to the aerosol generation mechanism. Also, the DMSderived aerosols and the wind-generated aerosols due to wave-breaking activity over the open ocean are the main sources for the observed aerosol concentration at $\mathrm{Ny}$-Alesund. The release of trapped DMS under sea ice may also contribute to the aerosol concentration.

The bubble bursting activity over the open oceanic surface introduces both film and jet drops
(Blanchard and Woodcock 1957; Blanchard 1963). In the central Arctic ocean, the production of film drops (Dp $\sim 100 \mathrm{~nm}$ ) of organic nature and jet drops $(\mathrm{Dp} \sim 1000 \mathrm{~nm}$ ) due to wind-driven source have been observed by Leck et al. (2002). This result is well evident in our observation of higher correlation of coarse mode particles with increasing wind speed (figure 6). Also, at lower wind speeds smaller waves generated over open oceans produce smaller and fewer bubbles in the colder water of pack ice. Another source of particle production is the air bubbles injected while ice melts (Drake 1968).

The winds approaching $\mathrm{Ny}$-Alesund from the oceanic sector during summer, have a long journey over the open ocean. Our observations of increasing particle concentration with increase in wind speed in this sector, strongly support the fresh sea-salt particles generation with enhanced bubble breaking activity at higher wind speeds over the Arctic open ocean. Recent observations of O'Dowd et al. (2004) show that such mechanisms may generate particles in both coarse and fine modes. Also, more DMS production over the open ocean may contribute to higher particle concentration in the fine mode during the Arctic summer. Our result of greater correlation of the coarse mode particles with wind speed as compared to that of accumulation mode particles is consistent with the field measurements of O'Dowd et al. (1997) and Leck et al. (2002). Further, it shows higher efficiency of winds for the generation of particles in coarse mode. On the other hand, when the winds are approaching from the south-east direction over the ice covered region of Svalbard, the airmass has to travel more than 24 hours over ice covered glaciers/mountains. The observation of smaller aerosol number concentration during southeasterly winds supports its reduction during the passage of airmass over ice covered region.

Our observations effectively demonstrate that during the drizzle/snowfall events the scavenging of aerosol particles by the drizzle/snowfall is an efficient process in the Arctic environment. Our results are in agreement with those of Andronache (2003) that aerosol size distribution of coarse mode particle is drastically affected very shortly (in the fraction of one hour) after rain starts. Stressing the importance of the scavenging mechanism on the Arctic summer, Garrett et al. (2011) showed that the fact that surface air in the Arctic is clean in summer is less due to inhibited transport of pollutants from mid-latitudes, and more due to efficient wet scavenging. Model results of Browse et al. (2012) also show that transition of high wintertime concentration to the low summertime concentration is controlled by the transition from ice-phase cloud scavenging to the more efficient warm cloud scavenging in the late spring troposphere. Results 
of both Garrett et al. (2011) and Browse et al. (2012) suggest that the seasonal cycle in Arctic aerosol is driven by a temperature-dependent scavenging process in which removal of aerosols is more efficient at high relative humilities and warm temperatures. These results lead to an interesting scenario where a warmer and wetter Arctic in future may also be cleaner due to negative Arctic climate feedback.

\section{Conclusions}

The main conclusions from our observations made at Ny-Alesund, Svalbard during AugustSeptember period in the International Polar Year 2007-2008 are as below:

- The number concentration of aerosol particles in the size range of $0.5-20 \mu \mathrm{m}$ diameter ranges from 0.11 to 6.06 particles $\mathrm{cm}^{-3}$ with an average value of 0.84 particles $\mathrm{cm}^{-3}$. The total number concentration exhibits a diurnal variation with a maximum at noon hours on fair-weather days. However, no such diurnal variation is observed on cloudy days with an overcast sky. As the airmass persists over the Arctic region for 4-5 days, the aerosols measured at Ny-Alesund are attributed to be mainly of marine origin and the reacted sea-salt particles.

- The particle number concentration increases with the wind speed when winds approach $\mathrm{Ny}-$ Alesund from the oceanic sector. However, such an increase in particle concentration with wind speed is not observed when winds approach this station from other directions.

- While the increase in total particle number concentration with increase in wind speed from the oceanic sector is spread over the whole size range of particles, the increase in coarse mode particles is more prominent than that of accumulation mode particles.

- Age of the airmass over pack ice is also a factor, other than wind speed, to determine particle concentration when winds are southwesterly at Ny-Alesund.

- The process of rainout/washout of particles due to drizzle/snowfall is effective in the Arctic summer. The particle concentration starts decreasing within a few minutes from the start of event but requires a few hours to be restored to the normal background level after the end of event.

\section{Acknowledgements}

The authors express their gratitude to the Director, Indian Institute of Tropical Meteorology, Pune and National Centre for Antarctic and Ocean Research,
Goa for participation in the first Indian Arctic expedition. The meteorological data provided by the Alfred Wegener Institute (AWI) is thankfully acknowledged. The authors gratefully acknowledge the NOAA Air Resources Laboratory (ARL) for the provision of the HYSPLIT transport and dispersion model and READY website (http://www. arl.noaa.gov/ready.html) used in this publication. AKK is thankful for financial support under the INSA Senior Scientist programme.

\section{References}

Andronache C 2003 Estimated variability of below-cloud aerosol removal by rainfall for observed aerosol size distributions; Atmos. Chem. Phys. 3 131-143.

Barrie L A and Barrie M L 1990 Chemical components of lower tropospheric aerosols in the high Arctic: Six years of observation; J. Atmos. Chem. 11 211-226.

Bigg E K, Leck C and Tranvik L 2004 Particulates of the surface microlayer of open water in the central Arctic Ocean in summer; Marine Chemistry 91 131-141.

Blanchard D C 1963 The electrification of the atmosphere by particles from bubbles from the sea; Prog. Oceanogr. $173-202$.

Blanchard D C and Woodcock A H 1957 Bubble formation and modification in the sea and its meteorological significance; Tellus 9 145-158.

Browse J, Carslaw K S, Arnold S R, Pringle K and Boucher O 2012 The scavenging processes controlling the seasonal cycle in Arctic sulphate and black carbon aerosol atmos; Chem. Phys. 12 6775-6798.

Comiso J C 2002 A rapidly declining perennial sea ice cover in the Arctic; Geophys. Res. Lett. 29 1956, doi: 10.29/2002GRL015650.

Covert D S, Kapustin V N, Bates T S and Quinn P K 1996 Physical properties of marine boundary layer aerosol particles of the mid-Pacific in relation to sources and meteorological transport; J. Geophys. Res. 101 6919-6930.

Drake J C 1968 Electrification accompanying the melting of ice crystals; Quart. J. Roy. Meteorol. Soc. 94 176-191.

Eleftheriadis K, Vratolis S and Nyeki S 2009 Aerosol black carbon in the European Arctic: Measurements at Zeppelin station, Ny-Alesund, Svalbard from 19982007; Geophys. Res. Lett. 36 L02809, doi: 10.1029/ 2008 GL035741.

Eneroth K, Kjellstrom E and Holemen K 2003 A trajectory climatology for Svalbard: Investigating how atmospheric flow patterns influence observed tracer concentrations; Phys. Chem. Earth, Parts A/B/C 28 1191-1203.

Engvall A C, Krejci R, Storm J, Treffeisen R, Scheele R, Hermansen O and Paatero J 2008 Changes in aerosol properties during spring-summer period in the Arctic troposphere; Atmos. Chem. Phys. 8 445-462.

Ferek R J, Hobbs P V, Radke L F, Herring J A, Sturges W T and Cota G F 1995 Dimethyl sulfide in the Arctic atmosphere; J. Geophys. Res. 100(D12) 26,093-26,104.

Garrett T J, Brattström Sara, Sharma Sangeeta, Douglas, Worthy E J and Novelli Paul 2011 The role of scavenging in the seasonal transport of black carbon and sulfate to the Arctic; Geophys. Res. Lett. 38 L16805, doi: 10.1029/2011GL048221.

Hassol S J 2005 Impacts of a Global Arctic - Arctic climate Impact Assessment; ACIA, Cambridge University Press. 
Heintzenberg J 1980 Particle size distribution and optical properties of Arctic haze; Tellus 32 251-260.

Heintzenberg J 1981 The chemical composition of Arctic haze at Ny-Alesund, Spitzbergen; Tellus 33 162171.

Heintzenberg J 1987 Chemically resolved submicrometric size distribution and external mixing of the Arctic haze aerosols; Tellus 39B 374-382.

Heintzenberg J, Covert D C and Van Dingenen R 2000 Size distribution and chemical composition of marine aerosols: A compilation and review; Tellus 52B 1104-1122.

Heintzenberg J, Leck C, Birmili, Wehner B, Tjernstorm $\mathrm{M}$ and Wiedensohler A 2006 Aerosol number-size distributions during clear and fog periods in the summer high Arctic: 1991, 1996 and 2000; Tellus 58B 41-50.

Hong Geng, Ji Yeon Ryu, Hae-Jin Jung, Hyeok Chung, Kang-Ho Ahn and Chul-Un Ro 2010 Single-particle characterization of summertime arctic aerosols collected at Ny-Alesund, Svalbard; Environ. Sci. Technol. 44(7) 2348-2353.

IPCC: Regional climate projections; In: Climate change 200\%: The physical basis, Contribution of the Working Group I to the Fourth Assessment Report of the Intergovernmental Panel on Climate Change 2007, Cambridge University Press.

Kasibhatla P, Chameides W L and St John J 1997 A three dimensional global model investigation of the seasonal variation in the atmospheric burden of anthropogenic sulfate aerosols; J. Geophys. Res. 102 3737-3759.

Lannerfors H, Heintzenberg J and Hansson H C 1983 A comprehensive study of physical and chemical parameters of the Arctic summer aerosol: Results from the Swedish expedition Ymer-80; Tellus 35B 40-54.

Leck C and Bigg E K 1999 Aerosol production over remote marine areas - A new route; Geophys. Res. Lett. 26 3577-3580.

Leck C and Persson C 1996 Seasonal and short-term variability in dimethylsulfide, sulfur dioxide and biogenic sulfur and sea-salt aerosol particles in the article marine boundary layer during summer and autumn; Tellus Ser. B 48 272-299.

Leck C, Nilsson E D, Bigg E K and Backlin L 2001 Atmospheric program on the Arctic ocean expedition 1996 (AOE-1996): An overview of scientific goals, experimental approach, and instruments; J. Geophys. Res. 106 $32,051-32,067$.

Leck C, Norman M and Bigg E K 2002 Chemical composition and sources of the high Arctic aerosol relevant for cloud formation; J. Geophys. Res. 107(D12) AAC-1-1-AAC-1-17, doi: 10.1029/2001JD001463.

Liss P S and Duce R A 1997 The Sea Surface and Global Change, Cambridge University Press, 520p.

Matrai P A, Tranvik L, Leck C and Knulst J C 2008 Are high Arctic surface microlayers a potential source of aerosol organic precursors?; Mar. Chem. 108 109-122.

Nilsson E D, Rannik U, Swietlicki E, Leck C, Aalto P P, Zhou J and Norman M 2001 Turbulent aerosol fluxes over the Article Ocean, 2, wind driven sources from the sea; J. Geophys. Res. 106 32,139-32,154.
O'Dowd C D and Smith M H 1993 Physiochemical properties of aerosol over the northeast Atlantic: Evidence for wind-speed-related submicron sea-salt aerosol production; J. Geophys. Res. 98 1137-1149.

O'Dowd C D, Smith M H, Consterdine I E and Lowe J A 1997 Marine aerosol, sea-salt and the marine sulphur cycle: A short review; Atmos. Environ. 31 73-80.

O'Dowd C D, Facchini M C, Cavalli F, Ceburnis D, Mircea M, Decesari S, Fuzzi S, Yoon Y J and Putaud J P 2004 Biological driven organic contribution to marine aerosol; Nature 431 676-680.

Pruppacher H R and Klett J D 2000 Microphysics of clouds and precipitation (London: Kluwer Academic Publishers), 954p.

Ricard V, Jaffrezo J L, Kerminen V M, Hillamo R E, Sillanpaa, Ruellan S, Liousse C and Cachier H 2002 Two years of continuous aerosol measurements in northern Finland; J. Geophys. Res. 107 4129, doi: 101029/ 2001JD000952.

Serreze M C, Holland M M and Stroeve J 2007 Perspectives on the Arctic's shrinking sea-ice cover; Science $\mathbf{3 1 5}$ 1533-1536.

Sharma S, Lavoué D, Cachier H, Barrie L A and Gong S L 2004 Long-term trends of the black carbon concentrations in the Canadian Arctic; J. Geophys. Res. 109 D15203, doi: 10.1029/2003JD004331.

Smith M H, Consterdine I E and Park P M 1989 Atmospheric loading of marine aerosol during a Hebredian cyclone; Quart. J. Roy. Meteorol. Soc. 115 383-395.

Stohl A 2006 Characteristics of atmospheric transport into the Arctic troposphere; J. Geophys. Res. 111 D11306, doi: 10.1029/2006JD007216.

Strom J, Umegard, Torseth K, Tunved P, Hansson H-C, Holmen K, Wismann V, Herber A and Konig-Langlo 2003 One year of particle size distribution and aerosol chemical composition measurements at the Zeppelin station, Svalbard, March 2000-2001; Phys. Chem. Earth, Parts $A / B / C 28$ 1180-1190.

Teinila K, Hillamo R, Kerminen V M and Beine $\mathrm{H} J$ 2003 Aerosol chemistry during the NICE dark and light campaigns; Atmos. Environ. 37 563-575.

Tomasi C, Vitale V, Lupi A, Carmine C Di, Campanelli M, Herber A, Treffeisen R, Stone R S, Andrews E, Sharma S, Radionov V, von Hoyningen-Huene W, Stebel K, Hansen G H, Myhre C L, Wehrli C, Aaltonen V, Lihavainen H, Virkkula A, Hillamo R, Ström J, Toledano C, Cachorro V E, Ortiz P, de Frutos A M, Blindheim S, Frioud M, Gausa M, Zielinski T, Petelski T and Yamanouchi T 2007 Aerosols in polar regions: A historical overview based on optical depth and in situ observations; J. Geophys. Res. 112 D16205, doi: 10.1029/2007JD008432.

Tomasi C, Lupi Angelo, Mazzola Mauro, Stone Robert S, Dutton Ellsworth G, Herber Andreas, Radionov Vladimir F, Holben Brent N, Sorokin Mikhail G, Sakerin Sergey M, Terpugova Svetlana A, Sobolewski Piotr S, Lanconelli Christian, Petkov Boyan H, Busetto Maurizio and Vito 2012 Vitale a An update on polar aerosol optical properties using POLAR-AOD and other measurements performed during the International Polar Year; Atmos. Environ. 52 29-47. 